\title{
Antimicrobial and P450 Inhibitory Properties of Common Functional Foods
}

San Nguyen ${ }^{1}$, Huang Huang ${ }^{2}$, Brian C. Foster ${ }^{1,3}$, Teresa W. Tam ${ }^{1}$, Tim Xing ${ }^{2}$, Myron L. Smith ${ }^{2}$, John T. Arnason ${ }^{1}$, Humayoun Akhtar.

${ }^{1}$ Centre for Research in Biopharmaceuticals and Biotechnology, University of Ottawa, 451 Smyth Rd. Ottawa, Ontario, Canada. ${ }^{2}$ Department of Biology, Carleton University, 1125 Colonel By Drive, Ottawa, Ontario, Canada. ${ }^{3}$ Previous address: Therapeutic Products Directorate, Health Products and Food Branch, 1600 Scott St. Ottawa, Ontario, Canada. ${ }^{4}$ Guelph Food Research Centre, Agriculture and Agri-Food Canada, 93 Stone Road West, Guelph, Ontario, Canada.

Received, April 23, 2014; Revised, May 24, 2014; Accepted, June 2, 2014; Published, June 5, 2014.

\begin{abstract}
PURPOSE: To study the effect of functional foods on human cytochrome P450 (CYP) and the gut bacterial microflora that may potentially affect drug metabolism and ultimately affect human health and wellness. METHODS: This study examined a variety of food plants from the Apiaceae, Fabaceae, and Lamiaceae families for their inhibitory potential on cytochrome 2D6-, 3A4-, 3A5-, and 3A7-mediated metabolism. The antimicrobial effects of these samples were also investigated with 7 selected bacterial surrogate species to determine potential effects on the gut microflora. RESULTS: The highest CYP inhibitory activities, based upon visual examination, were observed from extracts of celery seed, cumin, fennel seed, basil, oregano, and rosemary belonging to the Apiaceae and Lamiaceae families, respectively. Likewise, the strongest antimicrobial activities were also observed in the Apiaceae and Lamiaceae. No significant antimicrobial and CYP inhibition was observed in the Fabaceae extracts. CONCLUSION: Results demonstrated the possible risk of food-drug interactions from spice and herb plants may affect drug disposition and safety.
\end{abstract}

This article is open to POST-PUBLICATION REVIEW. Registered readers (see "For Readers") may comment by clicking on ABSTRACT on the issue's contents page.

\section{INTRODUCTION}

Increased health awareness has led many consumers to become more vigilant in maintaining good health. Many consumers have incorporated natural health products (NHPs) and functional foods (foods selected for beneficial health properties) into their daily lives to achieve optimal health and wellness. A report released by Health Canada in 2005 estimated that $71 \%$ of the Canadian population uses NHPs on a daily basis (1). At the same time a Canadian survey reported that $47 \%$ of those who use prescription drugs and natural health products together had adverse effects ranging from mild to severe rashes and serious effects by those who used blood thinners etc (2). Both functional foods and NHPs selected for health benefits contain bioactive secondary metabolites but their roles in promoting human health has not been thoroughly studied (3). The high levels of bioactive phytochemicals in some diets have also raised concerns about possible food-drug and NHP-drug interactions.
Functional foods and NHPs contain bioactive compounds that are metabolized by cytochrome P450 enzymes (CYP) and may affect drug metabolism thereby resulting in a higher plasma concentration of xenobiotics and drugs exceeding the dose required for adverse drug reaction. Some of the major CYP enzymes involved in the metabolism of these products are CYP2D6, CYP3A4, CYP3A5 and CYP3A7. It is well established that grapefruit juice can cause interaction with conventional drugs $(4,5)$. It was found that furanocoumarins (FC) from grapefruit juice was responsible for mechanism-based inhibition of CYP activity, 6', 7'dihydroxybergamottin being one of several FCs identified (6). Recent studies have also reported that star fruit and pomegranate juice may also inhibit

Corresponding Author: Brian C. Foster, Ph.D Centre for Research in Biopharmaceuticals and Biotechnology, University of Ottawa, 451 Smyth Rd. Ottawa, Ontario, K1H 8M5, Canada; Email: bfoste2@uottawa.ca 
drug metabolism $(7,8)$.

The human colon contains over 400 species of bacteria and these bacteria produce a wide spectrum of reductive and hydrolytic enzymes that can metabolize xenobiotics (9). Studies have shown that small amounts of drug metabolites produced from the gut microflora could also alter the P450 enzymes and change the metabolism and toxicity of a drug in the host (10). One example of the effect of the microflora on drug disposition is with digoxin. A higher percentage of the North American population relative to a population from southern India converts digoxin to reduced metabolites (11) suggesting that consideration of human gut microbial activities should be part of any treatment regimen. Due to the symbiotic and mutualistic microflora, and host relationship (12), variability in the composition and abundance of the gut microflora may cause variation in $\mathrm{P} 450$ response to drugs and toxins. Therefore, bacterial flora in the human gut can play an important role in the absorption, bioactivity and bioavailability of drugs. Foods containing secondary compounds that are antimicrobial may, therefore, alter drug activities. This may further exacerbate the pharmacological action of phytochemicals on the CYP enzymes.

Functional foods are complex products and may contain many pharmacologically active phytochemicals, and these active ingredients may possess multiple biological activities rather than having only one effect on human health. The CYP inhibition and antimicrobial activity of foods may be related to the class of phytochemicals present and each activity may react differently to different groups of phytochemicals, and as such may impact population differently based on diets.

To broaden understanding of drug-food interactions, this study examined a priority group of pulses, spices and herbs on the Canadian market selected by Agriculture and Agri-Food Canada (AAFC) to determine their potential risk for inhibiting human CYP enzymes (Table 1) and affect selected gut microflora. Samples were selected from the Fabaceae which contain isoflavones, Apiaceae which contain furanocoumarins, and Lamiaceae which contain monoterpenes, and tested for potential inhibition against CYP2D6, CYP3A4, CYP3A5 and CYP3A7. Seven representative gut bacterial genera were selected for the antimicrobial screening. By testing many common food samples, the assessment of potential food-drug interactions and antimicrobial activities across a broad spectrum of diets and therapeutic use of functional foods was achieved.

\section{MATERIALS AND METHODS}

\section{Chemicals and reagents}

CYP enzymes 3A4 (Human CYP3A4 + reductase, $1 \mathrm{nM}, 500 \mathrm{uL}$ - Cat\# 456207), 3A5 (Human CYP3A5 + reductase, $1 \mathrm{nM}, 500 \mathrm{uL}$ - Cat\# 456235), 3A7 (Human CYP3A7 + reductase + b5, $0.5 \mathrm{nM}, 500 \mathrm{uL}-\mathrm{Cat} \#$ 456237), 2D6 (Human CYP2D6*1 + P450 reductase supersomes - Cat\# 455117), dibenzylfluoroscein (DBF), and 3-[2(N,N-diethyl-N-methylamino)ethyl]-7-methoxy-4methylcoumarin (AMMC) were obtained from Gentest (Franklin Lakes, NJ, USA). All enzymes were stored at $-80^{\circ} \mathrm{C}$ until required. NADPH $(\beta-$ NADPH reduced tetrasodium salt hydrate - Cat\# N7505-1GR), was from Sigma Aldrich (Oakville, $\mathrm{ON}$, Canada) and stored at $-20^{\circ} \mathrm{C}$ under very low light conditions. Ketoconazole was purchased from Calbiochem (Gibbstown, NJ, USA). Methanol was purchased from Fisher Scientific Canada (Ottawa, ON, Canada).

\section{Sample collection}

All samples come from local supermarkets or farms in the Ottawa or Guelph areas of Ontario, Canada. Each sample was given a Nutraceutical Research Program (NRP) number and all pertinent information such as mass, company name, origin and place of purchase was recorded (see full description and full genus names in main text reference) (Table 1). Each sample was weighed and divided into three portions. One portion was stored in $-20^{\circ} \mathrm{C}$ for archiving at the University of Ottawa Herbarium and the remaining two portions were ground up into a fine powder, using a ThomasWiley industrial grinder with a $1 \mathrm{~mm}$ pore industrial grade steel mesh filter for consistency. One of the two portions of ground material was then stored for long term use at $-20^{\circ} \mathrm{C}$ until required and the last portion was stored at $-4^{\circ} \mathrm{C}$ for daily extractions.

\section{Sample extraction}

To prepare stock extracts of each sample, a dry weight of $50 \mathrm{mg} / \mathrm{mL}$ aliquot was mixed with $80 \%$ aqueous methanol $(\mathrm{v} / \mathrm{v})$ in a $2 \mathrm{~mL}$ centrifuge tube and blended on a Fisher Vortex Genie 2 at maximum settings for 2 minutes. 
Table 1 - Products selected their potential to affect human cytochrome P450-mediated metabolism. NRP, Nutraceutical Research Program number.

\begin{tabular}{|c|c|c|c|c|}
\hline NRP \# & Botanical Name & Common Name & Family & Country of origin \\
\hline 320 & Glycine $\max$ & Soybean & Fabaceae & Canada \\
\hline 321 & Glycine $\max$ & Soybean & Fabaceae & Canada \\
\hline 322 & Glycine $\max$ & Soybean & Fabaceae & Canada \\
\hline 323 & Glycine $\max$ & Soybean & Fabaceae & Canada \\
\hline 324 & Glycine $\max$ & Soybean & Fabaceae & Canada \\
\hline 325 & Glycine $\max$ & Soybean & Fabaceae & Canada \\
\hline 326 & Glycine $\max$ & Soybean & Fabaceae & Canada \\
\hline 327 & Glycine $\max$ & Soybean & Fabaceae & Canada \\
\hline 328 & Glycine $\max$ & Soybean & Fabaceae & Canada \\
\hline 329 & Glycine $\max$ & Soybean & Fabaceae & Canada \\
\hline 330 & Glycine $\max$ & Soybean & Fabaceae & Canada \\
\hline 331 & Glycine $\max$ & Soybean & Fabaceae & Canada \\
\hline 335 & Phaseolus vulgaris & Black Bean & Fabaceae & Imported* \\
\hline 313 & Phaseolus vulgaris & Black Turtle Bean & Fabaceae & Canada \\
\hline 314 & Phaseolus vulgaris & Cranberry Bean & Fabaceae & Canada \\
\hline 356 & Phaseolus vulgaris & Great Northern Bean & Fabaceae & USA \\
\hline 315 & Phaseolus vulgaris & Dark Red Kidney Bean & Fabaceae & Canada \\
\hline 316 & Phaseolus vulgaris & Lt† Red Kidney bean Var A & Fabaceae & Canada \\
\hline 317 & Phaseolus vulgaris & Lt Red Kidney bean Var. B & Fabaceae & Canada \\
\hline 318 & Phaseolus vulgaris & White Kidney bean Var. A & Fabaceae & Canada \\
\hline 319 & Phaseolus vulgaris & White Kidney bean Var. B & Fabaceae & Canada \\
\hline 339 & Phaseolus vulgaris & White Kidney bean Var. C & Fabaceae & Imported \\
\hline 354 & Phaseolus vulgaris & White Kidney bean Var. D & Fabaceae & Imported \\
\hline 337 & Phaseolus vulgaris & Navy Bean & Fabaceae & Imported \\
\hline 357 & Phaseolus vulgaris & Pinto Bean & Fabaceae & Canada/USA \\
\hline 358 & Phaseolus vulgaris & Small Red Bean & Fabaceae & Canada/USA \\
\hline 355 & Lens culinaris & Eston Lentil & Fabaceae & Imported \\
\hline 350 & Lens culinaris & Green Lentil & Fabaceae & Canada \\
\hline 359 & Lens culinaris & Red Lentil & Fabaceae & Canada \\
\hline 336 & Phaseolus. lunatus & Lima Bean & Fabaceae & Imported \\
\hline 351 & Pisum sativum & Green Pea & Fabaceae & Canada \\
\hline 352 & Pisum sativum & Yellow Pea & Fabaceae & Canada \\
\hline 338 & Pisum sativum & Yellow Split pea & Fabaceae & Imported \\
\hline 332 & Vigna unguiculata & Black Eyed Pea & Fabaceae & Imported \\
\hline 334 & Vigna unguiculata & Cow Pea & Fabaceae & Imported \\
\hline 353 & Cicer arietinum & Chick pea & Fabaceae & Canada \\
\hline 333 & Cicer cayan & Congo Pigeon pea & Fabaceae & Imported \\
\hline 341 & Apium graveolens & Celery seed A & Apiaceae & Imported \\
\hline 342 & Apium graveolens & Celery seed B & Apiaceae & $\mathrm{N} / \mathrm{A}$ \\
\hline 343 & Coriandrum sativum & Coriander & Apiaceae & $\mathrm{N} / \mathrm{A}$ \\
\hline 344 & Cuminum сутіпит & Cumin & Apiaceae & N/A \\
\hline 345 & Anethum graveolens & Dill & Apiaceae & N/A \\
\hline 346 & Foeniculum vulgare & seed & Apiaceae & $\mathrm{N} / \mathrm{A}$ \\
\hline 340 & Ocimum basilicum & Basil leaves & Lamiaceae & Imported \\
\hline 347 & Origanum vulgare & Oregano leaves & Lamiaceae & Imported \\
\hline 348 & Rosemarinus officinalis & Rosemary & Lamiaceae & Imported \\
\hline
\end{tabular}

* this was the designation on the product label. $\uparrow 1$ t, light. 
The sample was then centrifuged in a Fisher Scientific (Ottawa, ON, Canada) Micro12 Centrifuge at $13,000 \mathrm{~g}$ for 20 minutes. The supernatant was stored in an opaque container at $4^{\circ} \mathrm{C}$. Aqueous and ethanol samples were prepared as described above. Extracts were freshly prepared daily.

\section{Fluorometric microtitre cytochrome P450 inhibition assays}

A fluorometric microtitre plate assay was used to assess the inhibitory capacities of the plant extracts against CYP3A4, 3A5, 3A7 and 2D6. The procedure used was adapted and modified from Crespi et al. (13) and Scott et al. (14). The assays were performed in 96-well plates with white walls and clear, flat bottoms under red-coloured light to minimize the exposure of fluorescent light to photosensitive material (i.e. NADPH, quinidine, substrates, extracts). The fluorescence was measured using a Cytofluor 4000 Fluorescence Measurement System (Applied Biosystems, Foster City, CA, USA). The percent inhibition for each extract was calculated relative to the CYP activity in the presence of the vehicle control. A $10 \mu \mathrm{L}$ aliquot of each extract, at a concentration of 50 $\mathrm{mg} / \mathrm{mL}$, was tested in triplicate. Each assay was repeated at least once. All extracts were freshly made on experimental days and the remainders discarded.

Wells were designated as "control," "control blank," "sample," or "sample blank." The control represented the $\mathrm{MeOH}$ vehicle control, whereas the sample represented the extract or positive control. Solution A contained $1.08 \mathrm{mM}$ NADPH and the substrate in $0.25 \mathrm{M}$ potassium phosphate buffer solution, $\mathrm{pH}$ 7.4. Solution B contained the CYP in the $0.13 \mathrm{M}$ buffer solution. Solution $\mathrm{C}$ was identical to Solution B but instead contained denatured CYP rather than active enzyme ("blank"). A volume of $100 \mu \mathrm{L}$ of Solution A was added to each well followed by the addition of $10 \mu \mathrm{L}$ of the extract. Enzyme was thawed prior to its addition to Solution $\mathrm{B}$ or $\mathrm{C}$ and a $90 \mu \mathrm{L}$ aliquot of this mixture which was immediately added to each well. The plate was shaken for three seconds, and the initial fluorescence was measured at excitation and emission wavelengths depending on the substrate and product, respectively, as described below. The plate was then incubated at $37^{\circ} \mathrm{C}$ for 20 to 40 minutes depending on the enzyme tested and then final fluorescence was measured.
The concentration of CYP3A4, 3A5, and 3A7 used was $10 \mu \mathrm{M}$ with $\mathrm{DBF}$ as a substrate at concentrations of $1 \mu \mathrm{M}$. The positive inhibitor used was ketoconazole at a concentration of $1.9 \mu \mathrm{M}$. Samples were read at excitation wavelength of 485 $\mathrm{nm}$ and an emission wavelength of $530 \mathrm{~nm}$ with gain set at 50. The concentration of CYP2D6 used was $10 \mu \mathrm{M}$ with AMMC as a substrate at a concentration of $0.12 \mu \mathrm{M}$ and quinidine as a positive inhibitor at a concentration of $2 \mu \mathrm{M}$. The samples tested against CYP2D6 were read with excitation wavelength of $409 \mathrm{~nm}$ and emission wavelength of $460 \mathrm{~nm}$ with gain set at 50 . The incubation time was 20 minutes for CYP3A4 and $3 \mathrm{~A} 5$ assays and 40 minutes for CYP3A7 and 2D6 assays.

\section{Antimicrobial assay}

Extracts were examined by antimicrobial assays using the Kirby-Bauer disc diffusion assay (40). Both methanolic and ethanolic extracts were tested. A total of 7 bacterial species were selected in this study from different genera. There were 3 Gram (+) bacterial species: Bacillus subtilis, Enterococcus faecalis, and Listeria innocua, and 4 Gram (-) bacterial species: Escherichia coli, Pseudomonas putida, Providencia stuartii, and Acetobacter calcoaceticus. Each bacterial species was inoculated in $10 \mathrm{~mL}$ of Mueller-Hinton medium and cultured over night at $37^{\circ} \mathrm{C}$, and then plated using a sterile cotton swab onto Mueller-Hinton agar in Petri dishes. A $20 \mu \mathrm{L}$ aliquot of the sample extract was transferred onto a $5 \mathrm{~mm}$ bacteria susceptibility disc (Oxoid, Nepean, ON, Canada). Sample discs were then air dried and placed in triplicate onto the inoculated agar surface. The Petri dishes were then incubated at $37^{\circ} \mathrm{C}$ in dark condition and the zones of inhibition were measured at 24 hours. Ciprofloxacin was used as the positive control against all 7 bacterial species.

\section{RESULTS}

A total of 46 food samples were examined in this study: 37 Fabaceae, 6 Apiaceae, and 3 Lamiaceae. The CYP inhibitory potential of each sample was categorized as low $(<35 \%)$, moderate $(35-70 \%)$ and high $(>70 \%)$ inhibition. Apiaceae and Lamiaceae methanolic extracts had the highest CYP3A4 inhibition (Figure 1A). 
A

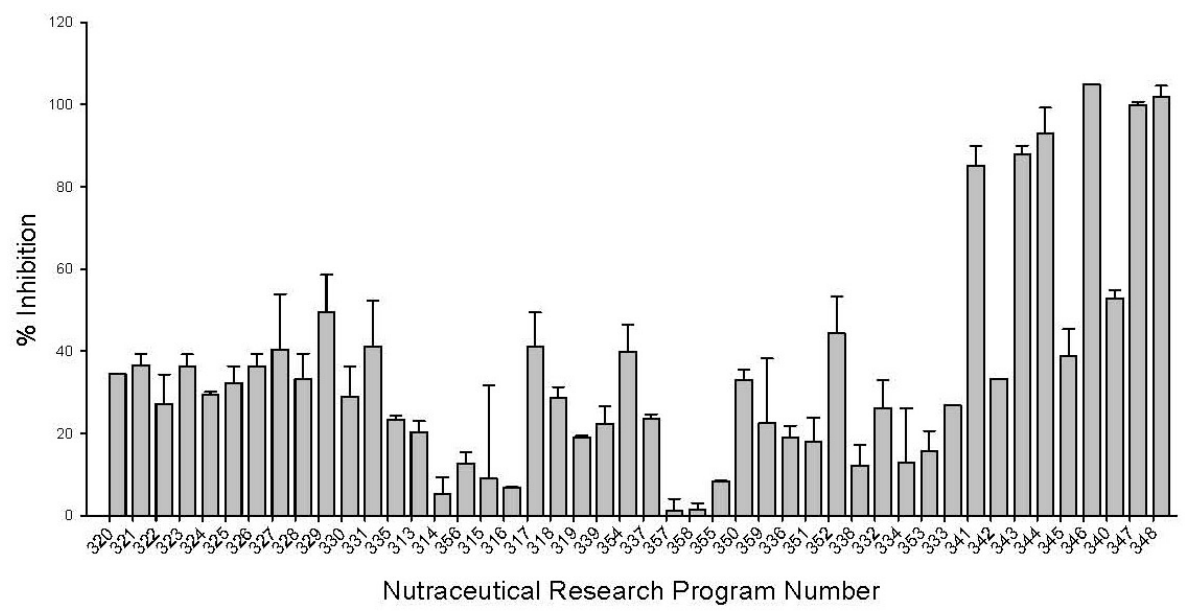

$\mathrm{B}$

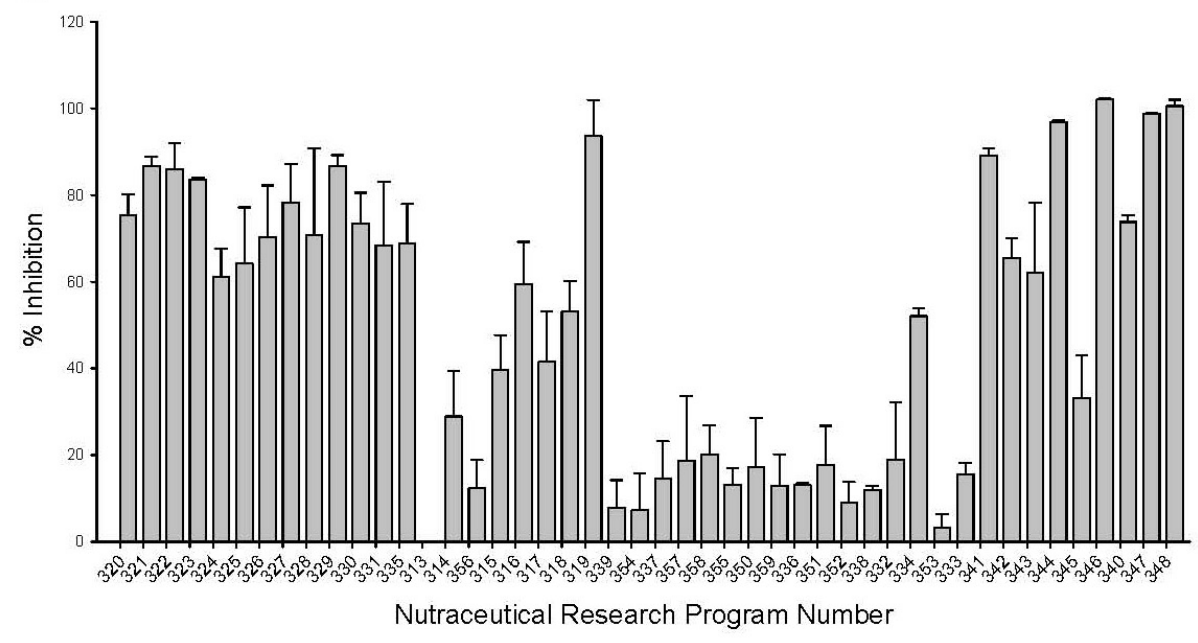

Figure 1 - Percent inhibition of methanolic (A) and aqueous (B) extracts $(50 \mathrm{mg} / \mathrm{mL})$ from common food samples on cytochrome P450 3A4 isozyme. Values are presented as means \pm standard deviation.

Celery seed (var. A), coriander, cumin, and fennel seed of the Apiaceae and oregano and rosemary of the Lamiaceae inhibited CYP3A5 by over $85 \%$. Among the Fabaceae, soybean samples had low to moderate CYP3A4 inhibition. Remaining Fabaceae samples displayed low to moderate inhibition with the exception of light red kidney bean (var. B) and yellow pea having the highest inhibition of $41.2 \pm$ $8.2 \%$ and $44.4 \pm 8.8 \%$, respectively. Aqueous extracts had high inhibition (75- $100 \%$ ) values in several samples (Figure 1B). Fennel seed, cumin, and celery seed (var. A), rosemary, oregano and basil all displayed high levels of inhibition. Soybean samples all moderately inhibited CYP3A4. The remaining Fabaceae samples had low to moderate inhibition with the exception of white kidney bean (var. B) having stronger inhibition at $93.6 \pm 8.4 \%$. 
Apiaceae and Lamiaceae methanolic extracts had high inhibitory levels towards CYP3A5 (Figure 2A). Among the Fabaceae, soybean samples moderately inhibited CYP3A5 whereas the remaining Fabaceae samples displayed low inhibitory levels. Aqueous extracts displayed lower inhibition values in numerous samples (Figure 2B). The highest levels of inhibition were observed in cumin, celery seed (var. A) and celery seed (var. B), which were relatively moderate in comparison to the activity observed in the methanolic extracts. Rosemary and oregano were the most active, inhibiting at $99.6 \pm 0.5 \%$ and $74.9 \pm 3.4 \%$, respectively. Remaining Fabaceae samples had low to moderate inhibition.

In regards to CYP3A7, the Apiaceae and Lamiaceae methanolic extracts had the highest inhibition as seen previously in CYP3A5 (Figure $3 \mathrm{~A})$. The highest levels of inhibition were observed with fennel seed, cumin, and celery seed (var. A). Rosemary and oregano and basil also displayed high inhibitory levels. Soybean samples inhibited CYP3A7 at moderate and high levels whereas the remaining Fabaceae inhibited at low to moderate levels. The aqueous extracts generally had lower CYP3A7 inhibition values (Figure 3B). High levels of inhibition were observed in fennel seed, dill, and celery seed (var. B). Basil oregano and rosemary had moderate inhibition. The activity levels seen in soybean and the remaining Fabaceae samples were low to moderate and were more similar against the CYP3A7 than previously observed in the CYP3A4 and $3 \mathrm{~A} 5$ assay.

A

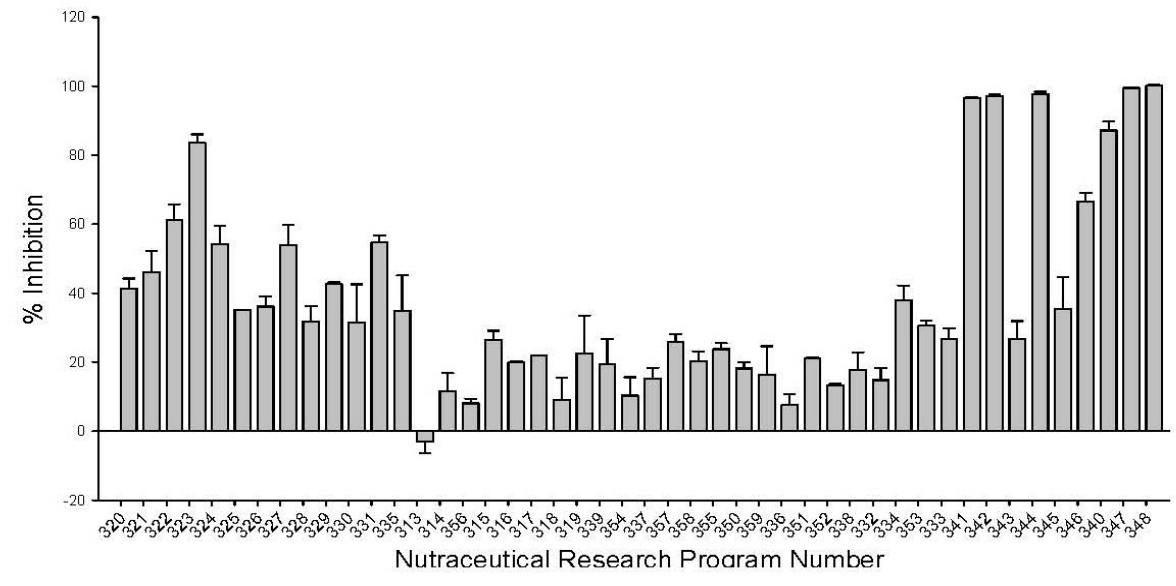

B

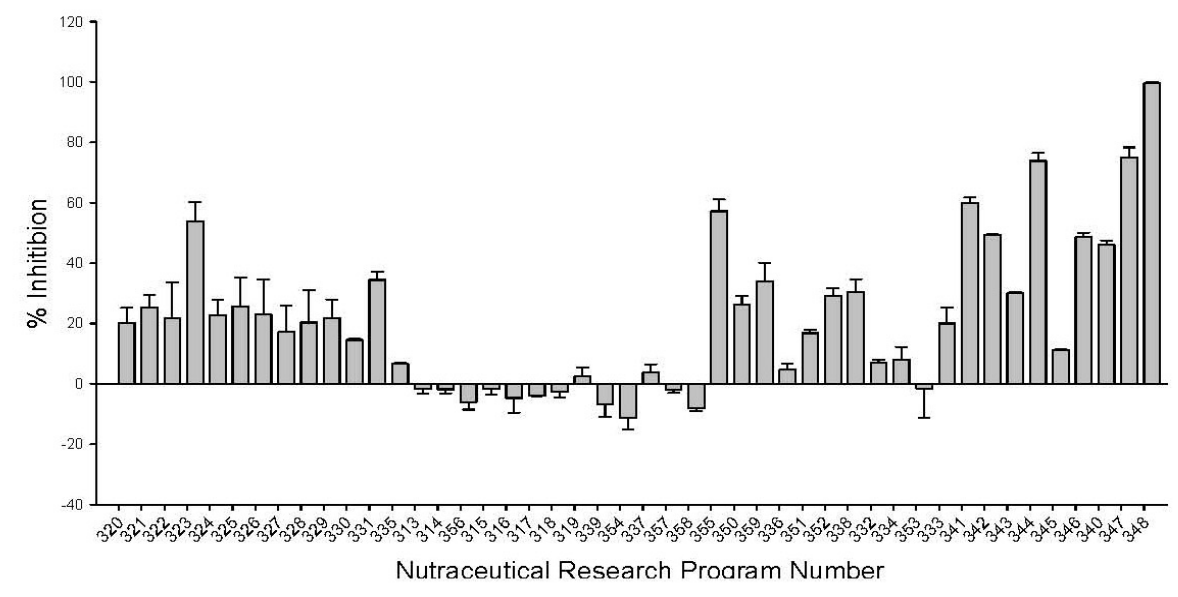

Figure 2. - Percent inhibition of methanolic (A) and aqueous (B) extracts $(50 \mathrm{mg} / \mathrm{mL}$ from common food samples on cytochrome P450 3A5 isozyme. Values are presented as means \pm standard deviation. 

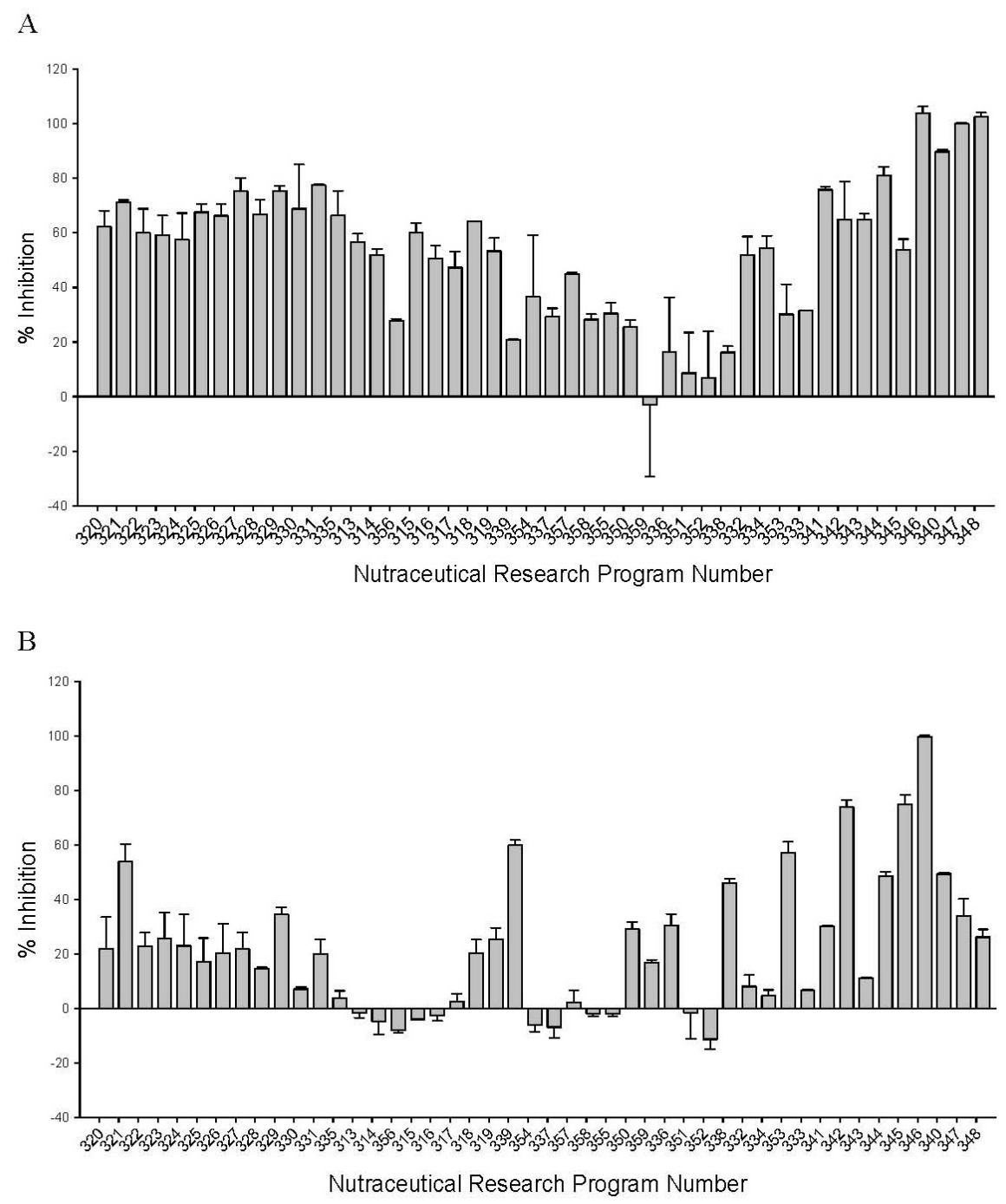

Figure 3. - Percent inhibition of methanolic (A) and aqueous (B) extracts $(50 \mathrm{mg} / \mathrm{mL})$ from common food samples on cytochrome P450 3A7 isozyme. Values are presented as means \pm standard deviation.

As previously highlighted from the results of CYP3A4, 3A5 and 3A7 data, the Apiaceae and Lamiaceae methanolic extracts had the highest CYP2D6 inhibition (Figure 4A). The highest levels of inhibition were observed in celery seed (var. A), celery seed (var. B), coriander, oregano and rosemary. Interestingly soybean samples had very low inhibition on CYP2D6. The remainder of the Fabaceae extracts also had low inhibition with the exception of light red kidney bean (var. B) which inhibited at $94.2 \pm 5.6 \%$. Aqueous extracts were similar to methanolic extracts (Figure 4B). The highest levels of inhibition were observed in celery seed (var. A), dill, coriander, rosemary and oregano. The aqueous extracts of basil, on the other hand, had a rather moderately low inhibition activity. Soybean and remaining Fabaceae samples also displayed low to moderate levels of inhibition.

The antimicrobial properties of the food samples were examined by the antimicrobial discdiffusion assay to evaluate potential effect on drug disposition by interacting with the gut bacterial microflora. The largest zones of inhibitions was observed with both methanolic and aqueous extracts of Apiaceae and Lamiaceae species shown in Table 2 , in concordance with high level inhibition of CYP enzyme by extracts of these same plants. Oregano leaves and rosemary demonstrated strong inhibitory activity against 6 of the 7 selected bacterial species, with the exception being A. calcoaceticus. Apiaceae 
extracts including cumin, dill, fennel seed, celery seed, and coriander also displayed relatively strong antimicrobial activities. Fennel seed extract showed the most potent antimicrobial effects with the largest zones of inhibitions in six out of the seven bacteria with the exception of E. coli. In comparison, celery seed demonstrated weaker antimicrobial effects and was only effective against $P$. putida and P. stuartii. None of the Apiaceae extracts were active against $E$. coli. No significant antimicrobial effect was observed in the Fabaceae extracts although a few Fabaceae samples demonstrated weak activity (less than $8 \mathrm{~mm}$ ) against $A$. calcoaceticus.

\section{DISCUSSION}

Through the evaluation of the 46 food-plant samples using 4 different CYP enzymes to determine the potential risk of food-drug interactions, the findings provide strong evidence that the selected Apiaceae and Lamiaceae samples, based on a visual examination of the data, have a higher potential than the Fabaceae products examined. The higher levels of activity in spices and herbs may be due to their selection for flavor, which is associated with a high level of phytochemicals (15).

A

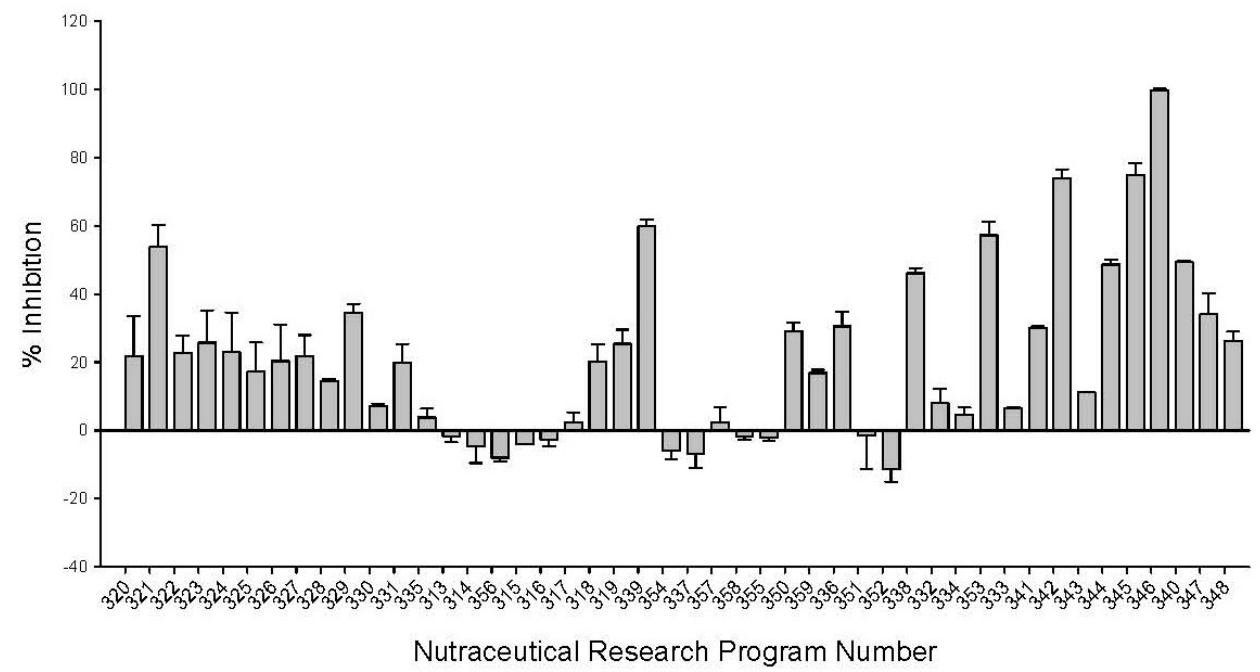

$\mathrm{B}$

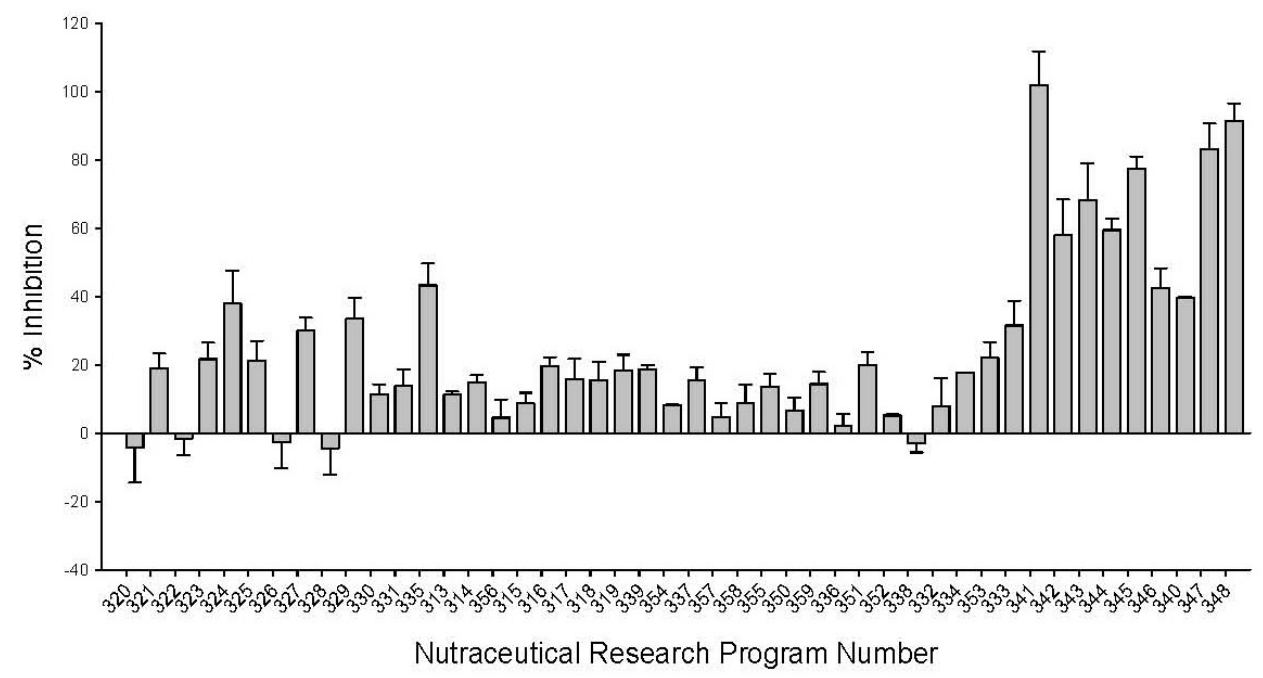

Figure 4. - Percent inhibition of methanolic (A) and aqueous (B) extracts $(50 \mathrm{mg} / \mathrm{mL})$ from common food samples on cytochrome P450 2D6 isozyme. Values are presented as means \pm standard deviation. 
An identical trend was observed in the examination of these plants for their antimicrobial effects with the Apiaceae and Laminaceae being the most active.

Some products such as fennel seed, celery seed and cumin exhibited consistently high levels of inhibition of all CYP enzymes tested, which may be attributed to high levels of FCs (16). The results obtained from fennel seed consistent with the report by Subehan et al. (16) that identified 5methoxypsoralen (5-MOP) as a mechanism-based inhibitor of CYP3A. Coriander and dill of the Apiaceae family, although also containing FCs (17) are not reported to express high levels of activity. The varying levels of inhibitory activity may be due to strain or chemotype differences, environmental factors related to growth and harvest conditions, instability during storage or transport, or processing (manufacturing) affecting the concentration or types of FCs present.

The data obtained in this study suggests that both methanolic and aqueous extracts of the Lamiaceae plants oregano and rosemary exhibit high levels of inhibition towards CYP enzymes. This high level of inhibitory activity may be attributed to the presence of flavonoids or aromatic monoterpenes and is consistent with studies reported in other flavonoid rich food plants such as pomegranate and rosemary $(8,18)$. Given the heightened popularity of antioxidants among the general public, the flavonoid-drug interactions may also be a problem that will increase. A review by Cermak (19) strongly cautions the possibility of flavonoid-drug interactions in functional foods and herbal supplements, and counsels the need for advisory labeling of unregulated products.

Among the Fabaceae in this study, the 12 soybean lines consistently exhibited moderately high inhibition activity against all 4 CYP isozymes. Previous studies have shown that aqueous extracts of soybean have the potential of inhibiting CYP3A4 and CYP3A7 and that hydrolyzed soy extracts at 50 $\mathrm{mg} / \mathrm{mL}$ can reduce CYP3A 4 activity by $22.3 \pm 5.9$ $\%$ compared to that of the control $(20,21)$. Lentil and other beans from other genera had lower inhibitory potential.

The antibacterial activities observed were predominantly from the Apiaceae and Lamiaceae. Among these, the highest and most broadly antibacterial activity, inhibiting 5 of the 6 bacterial strains, belonged to rosemary and oregano. Previous studies have shown oregano and rosemary to have high antibacterial activity against E. coli (22-24). Apiaceae extracts also produced high antibacterial activity with fennel possessing the strongest and broadest activity. Extracts from the Apiaceae family, namely dill, celery, coriander and fennel, have been shown to contain the antibacterial compounds falcarinol and falcarindiol (25). Zones of inhibition observed in this study may be affected by the loss of bioactive volatile phytochemicals and essential oils from the plant material due to processing and drying. A study using fresh plant material will be required to determine their full potential.

The antibacterial activities observed with the Fabaceae extracts were relatively low. The majority of the activities were from Phaseolus vulgaris varieties such as the light and dark red kidney bean, black bean, and black turtle bean. The data obtained correspond with previous studies and suggest that Fabaceae varieties containing coloured seed coats possessed stronger antibacterial activity as a result of secondary metabolites found in the seed coats (26). The coloured seed coats were observed to be a potential indication of bioactive secondary metabolites such as anthocyanins, condensed tannins and flavonoids (26).

By categorizing samples into families and evaluating their activity, two observations may be made about the secondary metabolomic content of a food crop, and its dietary selection as either a staple food or a condiment such spice and herb. First, the potential risk of food-drug interactions may be a characteristic of the plant family where there may be constitutive expression of compounds, such as FCs in Apiaceae (17). Likewise, the high activities in the Lamiaceae were also observed as a result of their high levels of secondary metabolites such as terpenoids, phenolics, and flavonoids (27). Traditionally, spices are used in minute amounts for their flavour and food preserving properties. Food spices and herbs typically contain higher levels of bioactive phytochemicals (28). Therefore this data suggests that the selected herbs and spices contain phytochemicals that can influence drug metabolizing enzymes and some bacterial species suggesting that there may also be an effect on the gut bacterial flora. Staple foods, consumed in larger volumes than spices, may not cause immediate or extreme biological activities; however this does not imply that they are absolutely safe as concentrations and biological activity may be intensified synergistically with time and volume. The results 
presented in this study are consistent with and extend earlier findings by our group that foodstuffs such as garlic (29), soy (30) and traditional West African plants (31) also have the potential to after CYP-mediated metabolism.

\section{CONCLUSIONS}

With the soaring popularity of NHPs and functional foods, many individuals are consuming larger quantities of these products such as soy, fresh herbs and spices. These products are deemed safe when consumed in reasonable amounts, but when consumed in larger amounts or together with other therapeutic products, the data obtain from this study indicates that there is a potential for drug interactions between functional foods and other therapeutic products. This may be an underlying cause or contributing factor for some drug overdoses, drug resistance or therapeutic failure. Although the majority of healthy individuals will see very little, if any, effect when consuming common food products, patients undergoing serious medical care should become more aware of potential risks identified with certain foods. More work is needed to examine the inhibitory properties of these samples under different sample selection criteria and extraction conditions. Studies are required to determine if there is an effect on the complex human gut microbiome.

\section{ACKNOWLEDGEMENTS}

Authors (S. Nguyen and H. Huang) equally contributed to this work and were financially supported as Research Affiliates by Agriculture and Agri-Food Canada. Authors gratefully acknowledge Jackie Moore and her consumer knowledge of the herbs and other products used in this study, and Michael Bryan for his valuable assistance during the course of this study.

\section{REFERENCES}

1. Murty, M. Postmarket surveillance of natural health products in Canada: Clin and federal regulatory perspectives, Can J Physiol Pharmacol, 85(9):952955, 2007.

2. Charrois, T.J., Hill, R.L., Vu, D., Foster, B.C., Boon, H.S., Cramer, K., and Vohra, S. Community identification of natural health product-drug interactions, Annal Pharmacother, 41:1124-1129, 2007.

3. Gurib-Fakim, A. Medicinal plants: Traditions of yesterday and drugs of tomorrow, Mol Asp Med, 27(1):1-93, 2006.

4. Bailey, D.G., Malcolm, J., Arnold, O., and Spence, J.D. Grapefruit juice-drug interactions, Br J Clin Pharmacol,46(2):101-110, 1998.

5. Bailey, D.G., Dresser, G.K., Kreeft, J.H., Munoz, C.D., Freeman, J., and Bend, J.R. Grapefruitfelodipine interaction: effect of unprocessed fruit and probable active ingredients. Clin Pharmacol Therapeut, 68(5):468-477, 2000.

6. Paine, M.F., Wilbur, W.W., Hart, H.L., Pusek, S.N., Beavers, K.L., Criss, A.B., Brown, S.S., Thomas, B.F., and Watkins, P.B. A furanocoumarin-free grapefruit juice establishes furanocoumarins as the mediators of the grapefruit juice-felodipine interaction. Am J Clin Nutr, 83:1097-1105, 2006.

7. Zhang, J.W., Liu, Y., Cheng, J., Li, W., Ma, H., Liu, H.T., Sun, J., Wang, L.M., He, Y.Q., Wang, Y., Wang, Z.T., and Yang, L. Inhibition of human liver cytochrome P450 by star fruit juice, J Pharm Pharmaceut Sci, 10(4):496-503, 2007.

8. Faria, A., Monteiro, R., Azevedo, I., and Calhau, C. Pomegranate juice effects on cytochrome P450s expression: in vivo studies, J Med Food, 10(4):643649, 2007.

9. Jain, S.K. and Jain, A. Target-specific drug release to the colon, Exp Opin Drug Deliv,5(5):483-488, 2008 .

10. Ingelman-Sundberg, M. Polymorphism of cytochrome P450 and xenobiotic toxicity, Toxicology, 181-182:447-452, 2002.

11. Nicholson, J.K., Holmes, E., and Wilson, I.D. Gut microorganisms, mammalian Metab personalized health care, Nat Rev Microbiol, 3(5)431-438, 2005.

12. Sears, C.L. A dynamic partnership: Celebrating our gut flora, Anaerobe, 11(5):247-251, 2005.

13. Crespi, C.L., Miller, V.P., and Penman, B.W. Microtiter plate assays for inhibition of human drugmetabolizing cytochrome P450, Analyt Chem, 248(1):188-190, 1997.

14. Scott, I.M., Leduc, R.I., Burt, A.J., Marles, R.J., Arnason, J.T., and Foster, B.C. The inhibition of human cytochrome $\mathrm{P} 450$ by ethanol extracts of North American botanicals, Pharmaceut Biol, 44(5):315-327, 2006.

15. Lampe, J.W. Spicing up a vegetarian diet: chemopreventive effects of phytochemicals, Am J Clin Nutrit, 78(3 Suppl):579-583, 2003.

16. Subehan, S.Z.F.H., Kadota, S., and Tezuka, Y. Inhibition on human liver cytochrome P450 3A4 by constituents of fennel (Foeniculum vulgare): Identification and characterization of a mechanism- 
based inactivator, J Agri Food Chem, 55(25):1016210168, 2007.

17. Cieśla, L., Bogucka-Kocka, A., Hajnos, M., Petruczynik, A., and Waksmundzka-Hajnos, M. Two-dimensional thin-layer chromatography with adsorbent gradient as a method of chromatographic fingerprinting of furanocoumarins for distinguishing selected varieties and forms of Heracleum spp., J Chrom, 1207(1-2):160-168, 2008.

18. Offord, E.A., Mace, K., Ruffieux, C., Malnoe, A., and Pfeifer, A.M.A. Rosemary components inhibit benzo[a]pyrene-induced genotoxicity in human bronchial cells, Carcinogenesis, 16(9)2057-2062, 1995.

19. Cermak, R. Effect of dietary flavonoids on pathways involved in drug metabolism, Exp Opin Drug Metab Toxicol, 4(1):17-35, 2006.

20. Anderson, G.D., Rosito, G., Mohustsy, M.A., and Elmer, G.W. Drug interaction potential of soy extract and Panax ginseng, J Clin Pharmacol, 43(6):643-649, 2003.

21. Foster, B.C., Vandenhoek, S., Hana, J., Krantis, A., Akhtar, M.H., Bryan, M., Budzinski, J.W., Ramputh, A. and Arnason, J.T. In vitro inhibition of human cytochrome P450-mediated metabolism of marker substrates by natural products, Phytomedicine, 10(4):334-342, 2003.

22. Sagdiç, O., Karahan, A.G., Özcan, M., and Özcan, G. Note: Effect of some spice extracts on bacterial inhibition, Food Sci Tech Int, 9(5):353-359, 2003.

23. Bozin, B., Mimica-Dukic, N., Simin, N., and Anackov, G. Characterization of the volatile composition of essential oils of some Lamiaceae spices and the antimicrobial and antioxidant activities of the entire oils, J Agri Food Chem, 54(5):1822-1828, 2006.

24. Romano, C.S., Abadi, K., Repetto, V., Vojnov, A.A., and Moreno, S. Synergistic antioxidant and antibacterial activity of rosemary plus butylated derivatives, Food Chem, 115(12):456-461, 2009.

25. Christensen, L.P., and Brandt, K. Bioactive polyacetylenes in food plants of the Apiaceae family: Occurrence, bioactivity and analysis, J Pharmaceut Biomed Anal, 41(3):683-693, 2006.

26. Beninger, C.W. and Hosfield, G.L. Antioxidant activity of extracts, condensed tannin fractions, and pure flavonoids from Phaseolus vulgaris L. seed coat color genotypes, J Agri Food Chem, 51(27):7879-7883, 2003.

27. Wink, M. Evolution of secondary metabolites from an ecological and molecular phylogenetic perspective, Phytochemistry, 64(1):3-19, 2003.

28. Sherman, P.W., and Hash, G.A. Why vegetable recipes are not very spicy, Evol Hum Behav, 22(3):147-164, 2001.

29. Foster, B.C., Foster MS, Vandenhoek S, Budzinski J, Gallicano KD, Choudri S, Krantis A, and Arnason JT. An In Vitro Evaluation of Human Cytochrome P450 3A4 and P-glycoprotein Inhibition by Garlic. J Pharm Pharmaceut Sci, 4(2):159-167, 2001.

30. Foster, B.C., Vandenhoek S, Hanna J, Budzinski JW, Akhtar MH, Bryan M, Krantis A, and Arnason JT. Effects of natural health products on cytochrome P-450 drug metabolism. Phytomedicine, 10(4):33442, 2003.

31. Agbonon, A., Eklu-Gdegbeku, K., Kodjo Aklikokou, K., Gbeassor, M., Tam, T.W., Arnason, J.T., and Foster, B.C. In Vitro Inhibitory Effect of West African Medicinal and Food Plants on Human Cytochrome P450 3A Subfamily, J Ethnopharmacol, 128(2):390-394, 2010. 
Table 2. - Antimicrobial effects of methanolic and ethanolic extracts of selected Apiaceae and Lamiaceae (50 mg/mL) against Bacillus subtilis, Enterococcus faecalis, Listeria innocua, Escherichia coli, Pseudomonas putida, Providencia sturatii, and Acetobacter calcoaceticus. Zones of inhibitions were determined according to the Kirby-Bauer disc diffusion assay. Values represent average inhibition zone diameters (mm \pm SD) based on triplicate experiments. Ciprofloxacin was used as the positive control. (-) denotes no inhibitory activity or a zone of inhibition of less than 6 mm, where disc diameter was 5 mm.

\begin{tabular}{|c|c|c|c|c|c|c|c|}
\hline & $\begin{array}{l}\text { B. subtilis } \\
(\text { Gram }+)\end{array}$ & $\begin{array}{l}\text { En. faecalis } \\
(\text { Gram }+)\end{array}$ & $\begin{array}{l}\text { L. innocua } \\
(\text { Gram }+)\end{array}$ & $\begin{array}{c}\text { E.coli } \\
\text { (Gram -) }\end{array}$ & $\begin{array}{l}\text { Ps. putida } \\
\text { (Gram -) }\end{array}$ & $\begin{array}{l}\text { P. stuartii } \\
\text { (Gram -) }\end{array}$ & $\begin{array}{c}\text { A. calcoaceticus } \\
\text { (Gram -) }\end{array}$ \\
\hline Cumin & $\begin{array}{l}8.3 \pm 0.6 \\
6.5 \pm 0.0\end{array}$ & $\begin{array}{l}- \\
-\end{array}$ & $\begin{array}{l}- \\
-\end{array}$ & - & $\begin{array}{l}11.5 \pm 0.0 \\
10.0 \pm 0.0\end{array}$ & - & $\begin{array}{l}7.5 \pm 0.0 \\
6.3 \pm 0.5\end{array}$ \\
\hline Fennel seed & $\begin{array}{c}10.7 \pm 0.8 \\
8.0 \pm 0.0\end{array}$ & $\begin{array}{c}10.5 \pm 0.0 \\
9.7 \pm 0.6\end{array}$ & $\begin{array}{c}10.5 \pm 0.0 \\
9.0 \pm 0.0\end{array}$ & $\begin{array}{l}- \\
-\end{array}$ & $\begin{array}{l}12.0 \pm 0.0 \\
9.7 \pm 0.6\end{array}$ & $\begin{array}{c}11.0 \pm 0.0 \\
9.0 \pm 0.0\end{array}$ & $\begin{array}{l}7.0 \pm 0.0 \\
6.0 \pm 0.0\end{array}$ \\
\hline Dill & $\begin{array}{l}- \\
-\end{array}$ & $\begin{array}{l}7.7 \pm 0.5 \\
6.3 \pm 0.4\end{array}$ & $\begin{array}{l}11.5 \pm 0.0 \\
10.3 \pm 0.8\end{array}$ & $\begin{array}{l}- \\
-\end{array}$ & $\begin{array}{l}7.0 \pm 0.0 \\
6.0 \pm 0.0\end{array}$ & $\begin{array}{c}12.5 \pm 0.0 \\
6.5 \pm 0.0\end{array}$ & $\begin{array}{l}7.3 \pm 0.5 \\
6.0 \pm 0.0\end{array}$ \\
\hline Celery seed & $\begin{array}{l}8.3 \pm 0.6 \\
6.5 \pm 0.0\end{array}$ & $\begin{array}{l}8.0 \pm 0.0 \\
7.5 \pm 0.0\end{array}$ & $\begin{array}{l}- \\
-\end{array}$ & $\begin{array}{l}- \\
-\end{array}$ & $\begin{array}{l}11.5 \pm 0.0 \\
9.3 \pm 0.6\end{array}$ & $\begin{array}{l}7.7 \pm 0.5 \\
6.0 \pm 0.0\end{array}$ & $\begin{array}{c}11.7 \pm 0.9 \\
8.0 \pm 0.0\end{array}$ \\
\hline Coriander & $\begin{array}{l}- \\
-\end{array}$ & $\begin{array}{l}- \\
-\end{array}$ & $\begin{array}{l}- \\
-\end{array}$ & $\begin{array}{l}- \\
-\end{array}$ & $\begin{array}{l}6.5 \pm 0.0 \\
6.5 \pm 0.0\end{array}$ & $\begin{array}{l}6.5 \pm 0.0 \\
6.0 \pm 0.0\end{array}$ & $\begin{array}{l}- \\
-\end{array}$ \\
\hline Rosemary & $\begin{array}{c}10.3 \pm 0.8 \\
8.3 \pm 0.6\end{array}$ & $\begin{array}{c}11.5 \pm 0.0 \\
9.0 \pm 0.0\end{array}$ & $\begin{array}{l}9.7 \pm 0.6 \\
8.5 \pm 0.0\end{array}$ & $\begin{array}{l}8.0 \pm 0.0 \\
6.0 \pm 0.0\end{array}$ & $\begin{array}{l}10.7 \pm 0.8 \\
8.0 \pm 0.0\end{array}$ & $\begin{array}{c}10.5 \pm 0.0 \\
9.3 \pm 0.6\end{array}$ & $\begin{array}{l}- \\
-\end{array}$ \\
\hline Oregano & $\begin{array}{l}7.0 \pm 0.0 \\
6.3 \pm 0.5\end{array}$ & $\begin{array}{l}12.0 \pm 0.0 \\
10.3 \pm 0.8\end{array}$ & $\begin{array}{l}9.5 \pm 0.0 \\
8.0 \pm 0.0\end{array}$ & $\begin{array}{c}10.5 \pm 0.0 \\
8.0 \pm 0.0\end{array}$ & $\begin{array}{c}10.5 \pm 0.0 \\
8.0 \pm 0.0\end{array}$ & $\begin{array}{c}11.5 \pm 0.0 \\
9.0 \pm 0.0\end{array}$ & $\begin{array}{l}- \\
-\end{array}$ \\
\hline Ciprofloxacin & $21.5 \pm 0.0$ & $23.0 \pm 0.0$ & $22.7 \pm 1.6$ & $28.5 \pm 0.0$ & $31.0 \pm 0.0$ & $27.0 \pm 0.0$ & $29.5 \pm 0.0$ \\
\hline
\end{tabular}

